From The Law and Theory of Trade Secrecy: A Handbook of

Contemporary Research, edited by Rochelle C. Dreyfuss and Katherine J. Strandburg, Edward Elgar (2011)

\title{
8 How trade secrecy law generates a natural semicommons of innovative know-how
}

Jerome H. Reichman*

It is both disappointing and exhilarating to re-examine the functions of trade secrecy law for this volume. The disappointment stems from encountering many of the same old questions that Reichman, Samuelson and Scotchmer have addressed over a 20 -year period. ${ }^{1}$ The exhilaration comes from rereading that brilliant article by Samuelson and Scotchmer on reverse engineering at some distance, and realizing how many questions these collective efforts managed to answer. So let me try to set the record straight in a few short pages, beginning with the question of whether or not it is better to treat trade secrecy law as a form of intellectual property law rather than as a business tort under unfair competition law. ${ }^{2}$

\section{TRADE SECRETS AS A FORM OF INTELLECTUAL PROPERTY}

The logical point of departure is to observe that 'intellectual property' has never been just about exclusive rights in intangible, non-rivalrous creations. It has always included conduct-based liability rules found in some sui generis regimes, as well as absolute liability rules that confer only a

* Bunyan S. Womble Professor of Law, Duke University School of Law, Durham, North Carolina.

The author gratefully acknowledges the support of the National Human Genome Research Institute and the Department of Energy (CEER Grant P50 HG003391, Duke University, Center of Excellence for ELSI Research).

1 J.H. Reichman, Charting the Collapse of the Patent-Copyright Dichotomy: Premises for a Restructured International Intellectual Property System, 13 CARDozo ARTs \& ENT. L.J. 475, 504-17 (1995); J.H. Reichman, Legal Hybrids Between the Patent and Copyright Paradigms, 94 Colum. L. Rev. 2432, 2504-57 (1994); Pamela Samùelson and Susan Scotchmer, The Law and Economics of Reverse Engineering, 888 YALE L.J. 1575 (2002).

2 Mark A. Lemley, The Surprising Virtues of Treating Trade Secrets as Intellectual Property Rights, 61 STAN. L. REV. 311, 315-53 (2008) (discussing the origins of trade secrecy law in torts, then constructing an IP theory of trade secrets); see also Gustavo Ghidini and Valeria Falce, Chapter 6. 
'license of right' yielding reasonable royalties, as occurs with mechanical recordings under copyright law and, in most countries, with public performances of sound recordings under neighboring rights laws. ${ }^{3}$ All of these are 'intellectuial property', which the classical tradition subdivides into 'industrial property' and 'literary and artistic property' (including neighboring rights laws). ${ }^{4}$

Formally, when international intellectual property law first recognized trade secrets under Article 39 of the TRIPS Agreement, the drafters deliberately inserted it into Article 10bis of the Paris Convention, which regulates unfair competition norms as a subset of industrial property law. ${ }^{5}$ The purpose of this move was to emphasize that Article 39 of the TRIPS Agreement had, in and of itself, not created any exclusive rights. Rather, it had recognized trade secret protection as a specification of the obligations to avoid unfair competition in international trade already set out in the Paris Convention. Unfortunately, the drafters of Article 39, which tracked the Uniform Trade Secrets Act (UTSA) in the United States, ${ }^{6}$ failed expressly to mention lawful reverse engineering. Yet, the understanding that reverse engineering is privileged perfects and operationalizes trade secret protection in the United States; its very purpose is to generate more innovation than would otherwise occur. ${ }^{7}$

If we think of intellectual property rights only as comprising exclusive rights, labeling trade secrets as 'intellectual property' deforms the entire history of trade secrecy law. But if we broaden our understanding of intellectual property to include all forms of property rights in intangible, non-rivalrous creations, including ex ante and ex post liability rules, then

3 See 17 U.S.C. $\$ 115$ (2006); International Convention for the Protection of Performers, Producers of Phonograms and Broadcasting Organizations, Rome, Italy, October 26, 1961, 496 U.N.T.S. 43 ('Rome Convention'), Art. 12.

4 See Berne Convention for the Protection of Literary and Artistic Works, September 9, 1886, as last revised at Paris, July 24, 1971, 828 U.N.T.S. 221 ('Berne Convention'); Arts. 1, 2; Paris Convention for the Protection of Industrial Property, March 29, 1883, as revised at Stockholm, July 14, 1967, U.S.T. 1583 ('Paris Convention'), Art. 1(1), (3); Rome Convention, Arts. 4-6.

5 Agreement on Trade-Related Aspects of Intellectual Property Rights, April 15, 1994, 33 I.L.M. 81 (1994) ('TRIPS Agreement'), Art. 39.1; Paris Convention, Art. 10bis. See generally Jerome H. Reichman, Rethinking the Role of Clinical Trial Data in International Intellectual Property Law: The Case for a Public Goods Approach, 13 MArQ. InTELl. Prop. L. Rev. 1, 17-22 (2009).

6 Compare Uniform Trade Secrets Act, \$1(2) 14 U.L.A. 438 (1985) with TRIPS Agreement, Art. 39.2.

7 See generally Samuelson and Scotchmer, supra note 1; RESTATEMENT (THIRD) OF TORTS $\$ 43$ (1995) ('Independent discovery and analysis of publicly available products or information are not improper means of acquisition'). 
we may say that there is a property right in trade secrets in the form of an entitlement to either lead time or compensation for lost lead time due to a wrongful appropriation. While there may or may not be an injunction to enforce that entitlement, the compensation is properly measured only in terms of the loss of lead time that it would have taken a routine engineer to reverse engineer the trade secret by honest means.

The modality of enforcement via an injunction in such cases does not convert trade secrecy law into a regime of exclusive property rights. It remains a conduct-based liability rule, but no less a property right, in the sense of an ex ante entitlement. It is, however, a peculiar property right, in that a third party's reverse engineering by honest means will truncate its existence without more. As the late Professor John C.Stedman accurately observed in 1962, it is 'a disappearing property right', unlike any other in that respect. ${ }^{8}$

It follows that treating trade secrets as an 'intellectual property right' does little in itself to advance our understanding. We must push on to consider what exactly trade secrecy law protects, and what its true normative function really is.

\section{TRADE SECRECY LAW PROTECTS INVESTMENT IN INNOVATION AS SUCH}

Viewed as a subset of intellectual property law, the distinctive characteristic of trade secrecy law is that it protects investment in innovation as such. Until the 1990s, when Switzerland tried to codify a misappropriation law for this very purpose (as Owen Paepke long ago desired), ${ }^{9}$ this distinctive aspect of trade secrecy law was virtually unique. ${ }^{10}$ By their nature, virtually all other so-called intellectual property rights (disregarding trademarks and the like) provide exclusive, non-exclusive or semi-exclusive rights to some predefined product of intellectual creativity, such as 'inventions' in patent

8 See John C. Stedman, Trade Secrets, 23 Ohio State L.J. 4, 8 (1962).

9 See Federal Law on Unfair Competition of December 1986, art. 5(c) (effective March 1, 1988) (Switz); Reichman, Legal Hybrids, supra note 1, at 2474-6; C. Owen Paepke, An Economic Interpretation of the Misappropriation Doctrine: Common Law Protection for Investments in Innovation, 2 HIGH TECH. L.J. 65 (1987); see also Douglas Gary Lichtman, The Economics of Innovation: Protecting Unpatentable Goods, 81 MinN. L. REv. 693 (1997).

10 But see Reichman, Legal Hybrids, supra note 1, at 2477-8 (describing the protection of construction project designs by means of an ex ante liability rule under art. 99 of the Italian Copyright Law). 
law, 'literary and artistic works' in copyright law, 'ornamental designs' (appearance designs) in design protection laws, or 'distinctive varieties' in plant variety protection law. ${ }^{11}$ These intellectual property rights, in turn, typically depend on the attainment of a specified level of creativity, as manifested in a specified type of intellectual creation, which will last for a specified period of time. The end result is to enable the creator to recoup his or her investment and turn a profit in the intangible, non-rivalrous creation, which might otherwise be duplicated rapidly (despite potentially high front-end costs, including R\&D costs, where applicable) and disseminated at relatively low marginal costs of reproduction.

As Stephen Ladas once explained, what trade secrecy law protects is an entrepreneur's investment in applications of know-how to industry, which may or may not rise to the level of a non-obvious invention. ${ }^{12}$ In this context:

know-how consists of information about how to achieve some technical or commercial advantage over competitors, typically by means of novel methods or processes of production. Such information may or may not be secret. If secret, it may be held only under actual, but not legal, secrecy, which in turn affects the degree of protection the law affords. ${ }^{13}$

This concept of know-how applied to industry has been successfully invoked to address the appropriation problems of innovations as diverse as applications interfaces in platform information technologies, ${ }^{14}$ traditional knowledge generated by indigenous communities, ${ }^{15}$ and clinical trial data. ${ }^{16}$ It therefore seems pointless to try to define the subject matter of trade secrecy laws in any other terms, although we must recognize that this same know-how may sometimes also qualify for protection as confidential information on other grounds and with different policies in mind. ${ }^{17}$

11 See generally $i d$. at $2448-72$.

12 Stephen P. Ladas, Patents, Trademarks and Related Rights: National and International Protection 1616 (1975).

13 Id. at 1617.

14 Samuelson and Scotchmer, supra note 1.

15 Jerome H. Reichman and Tracy Lewis, Using Liability Rules to Stimulate Innovation in Developing Countries: Application to Traditional Knowledge, in International Public GoOds and Transfer of TeChNology under a Globálized Intellectual Property Regime 321 (Keith E. Maskus and Jerome H. Reichman eds., Cambridge University Press, 2005).

16 Reichman, Role of Clinical Trial Data, supra note 5.

17 See generally J.H. Reichman, Overlapping Proprietary Rights in UniversityGenerated Research Products: The Case of Computer Programs, 17 ColuM. J.L. \& ARTS 51 (1992). 
Precisely because we are dealing with investments in know-how applied to industry as such, and not specified levels of creative achievement, classical trade secrecy law confers no exclusive property rights whatsoever. Rather, it provides a legal entitlement to a period of what I have earlier called 'natural lead time', during which a second comer may reverse engineer the originator's know-how from publicly available exemplars by honest means. ${ }^{18}$ Even for products of ordinary manufacture, this period of lead time could have been relatively long when the industrial revolution first got underway, although lead times today tend to be relatively short on the whole. ${ }^{19}$

Short or long, lead time conceptually enables a first comer to recoup investment in R\&D and to establish distinguishing trademarks that help to preserve profits against second comers who successfully reverse engineer the otherwise unprotected know-how. ${ }^{20}$ More importantly, the process of reverse engineering itself, by methodically extracting the innovator's know-how from a given application, tends to generate technical improvements over time, including cost-saving modes of manufacture that reduce prices to consumers. ${ }^{21}$ For example, the ballpoint pen, which entered the market through jewelry stores at U.S.\$70 per piece, is now available to everyone at $7 \varnothing$ a piece.

In so doing, trade secrecy law promotes healthy competition by securing investors in innovative applications of know-how to industry against market-destructive forms of free riding, while simultaneously stimulating these same third-party competitors to contribute to the technical community's aggregate costs of research and development:

In all cases, liability rules govern in the sense that, without permission, secondcomers may extract and improve preexisting industrial applications of knowhow as long as, in the absence of any contractual agreement to the contrary, they either defray the costs of reverse engineering or pay the equivalent costs of having usurped lead-time advantages by improper means. ${ }^{22}$

\footnotetext{
18`Reichman, Legal Hybrids, supra note 1, at 2439, and n.25.
}

19 See J.H. Reichman, Of Green Tulips and Legal Kudzu: Repackaging Rights in Subpatentable Innovation, 53 VAND. L. REV. 1743, 1750-1 (2000).

20 Of course, the second comer may prefer to purchase a license from the originator when the costs and/or the difficulties of reverse engineering appear formidable. See Samuelson and Scotchmer, supra note 1.

21 See, e.g., Leo J. Raskind, The Misappropriation Doctrine as a Competitive Norm of Intellectual Property Law, 75 MiNN. L. Rev. 875 (1991); Leo J. Raskind, The Semiconductor Chip Protection Act of 1984 and Its Lessons: Reverse Engineering, Unfair Competition, and Fair Use, 70 MrNN. L. Rev. 385 (1985).

22 J. H. Reichman, Saving the Patent Law from Itself, in PersPectives ON Properties of the Human Genome Project 289, 293 (F. Scott Kieff ed., Elsevier Press, 2003). 
From these observations, two important conclusions follow that merit further attention. First, the conduct-based liability rules of trade secrecy law were the primary vehicle for stimulating investment in innovative enterprise after the industrial revolution. This conclusion follows because most innovation consists of cumulative and sequential applications of know-how to industry by routine engineers at work on common technical trajectories. Given relatively high standards of non-obviousness in patent law, as well as the possibilities for inventing around patents once issued, most.commercial ventures depended on the conduct-based liability rules of trade secrecy law (and other unfair competition laws, as well as trademark law) for opportunities to recoup their investments in R\&D..$^{23}$ In this sense, trade secrecy laws mediated between the strong protection of patents, when available, and the risk of wholesale duplication (that is, the risk of zero lead time) in a totally unregulated environment of unbridled copying, as occurred in many developing countries before the TRIPS Agreement entered into force.

The second and more far-reaching conclusion is that this classical system of innovation gave rise to a naturally occurring pool of technological resources that was openly available to all routine engineers who played by the rules. Because this proposition has attracted insufficient study, it deserves a closer look here.

\section{A NATURAL OPEN-SOURCE TECHNOLOGY POOL}

The exclusive rights of classical intellectual property law may be viewed as operating in the space left free by two other regimes that intersect with them but which are governed by totally different principles. The three regimes taken together provide a rough map or outline of the classical system of innovation inherited from the industrial revolution. This scheme is represented in Figure 8.1. ${ }^{24}$ At the top of the diagram, lies the 'upstream' dimension, as it would be called today, in which scientific and technical knowledge is generated by the public science community, typically working at universities or other research centers. This basic research is often funded by government entities (in the United States,

23 See Reichman, Legal Hybrids, supra note 1; Reichman, Green Tulips, supra note 19 . Hence the old saying that intellectual property law provided only 'islands of protection in a sea of free competition', which is no longer in vogue today.

24 Reproduced and modified from Reichman, Saving the Patent System, supra note 22 , at 292 . 
COMMONS

Basic scientific and technical information

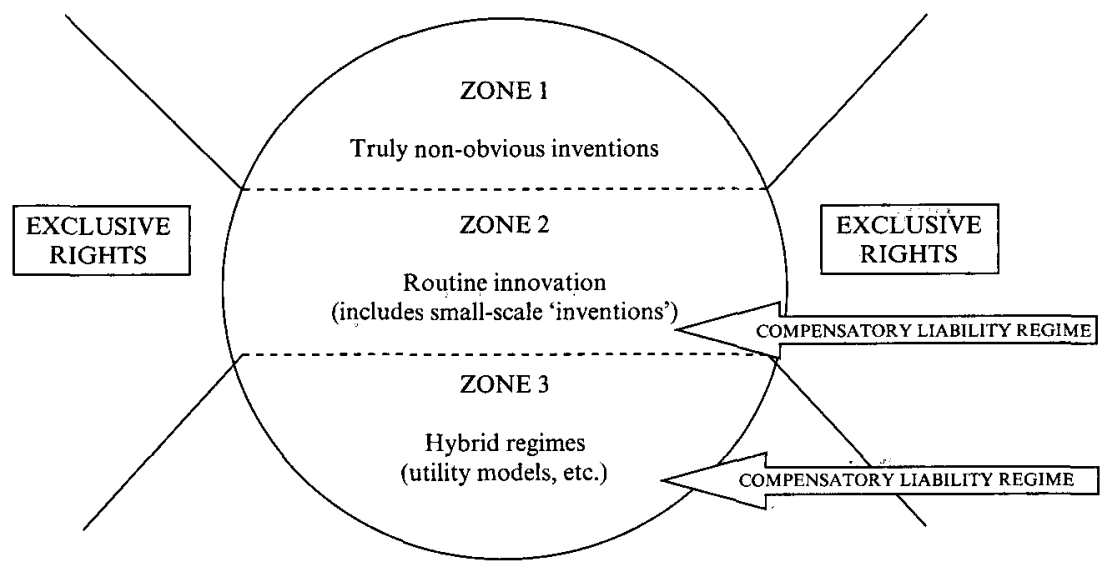

Applications of know-how to industry

SEMICOMMONS

Traditional trade secrets law

Figure 8.1 Expansion of exclusive rights in lieu of actual or legal secrecy

this would include the National Science Foundation (NSF), the National Institutes of Health (NIH), or the Department of Energy (DOE)), as well as by universities themselves, foundations, and even private industry, in support of basic research that can lead to downstream applications. ${ }^{25}$ In its most enlightened embodiment, this sphere of activity is one in which scientific and technical information flow freely as a relatively unregulated input, governed by the norms of science. ${ }^{26}$ Subject to growing pressures of a legal, technical and economic nature, the scientific and technical data and information generated here are, in principle, destined to become freely available to other scientists in what ideally approximates a true

25 See, e.g., Arti K. Rai and Rebecca S. Eisenberg, Bayh-Dole and the Progress of Biomedicine, 66 Law \& ConTEMP. Pross. 289 (2003); Anthony So et al., Is BayhDole Good for Developing Countries? Lessons from the U.S. Experience, 6 PLos Biology 2078 (2008), available at www.plosbiology.org/article/info:doi/10.1371/ journal.pbio.0060262.

${ }_{26}$ Arti K. Rai, Regulating Scientific Research: Intellectual Property Rights and the Norms of Science, 94 Nw. U. L. REV. 77 (1999). 
commons, one that has played a fundamental role in our national system of innovation. ${ }^{27}$

It is, however, in the lesser-known domain, deep in the bowels of the free enterprise economy, where scientific and technical know-how are applied to industry, that we must focus primary attention in this chapter. In Figure 8.1, this space is represented as lying under the sphere in which the exclusive rights of intellectual property law otherwise predominate (Zones 2 and 3). In this vast space, trade secrecy laws traditionally govern the productions of routine engineers who develop applications of knowhow to industry without securing patent protection..$^{28}$

Within this space, the reverse engineering clause built into the trade secret paradigm operates as an open invitation to third parties to make use of the first comer's innovative know-how for certain purposes, especially for devising improvements, or in exchange for compensation. The routine engineers working on common technical trajectories thus basically constitute an interrelated group that operates under a de facto sharing ethos. As explained in an earlier article:

[t]hey form a natural, open-source community built around the practice of reverse engineering and the availability of adequate lead time under the liability rules governing trade secrets and confidential information. In this endeavor, routine engineers depend on the reciprocal insights and contributions that the relevant technical communities derive from the [pooled] domain - the shared body of knowledge that underlies the common technical trajectories - and on their inability to remove novel insights and cumulative contributions to knowhow from [that domain]. ${ }^{29}$

However, unlike the scientific commons depicted 'upstream', the newest technical knowledge emerging in real time under the aegis of trade secrecy laws is typically available to routine engineers only on condition either

27 See, e.g., Paul David, The Economic Logic of 'Open Science' and the Balance Between Private Property Rights and the Public Domain in Scientific Data and Information: A Primer, in The Role of Scientific and Technical Data and Information in the Public Domain 19 (Julie M. Esanú and Paul F. Uhlir eds., NAS Press, 2003); J. H. Reichman and Paul F. Uhlir, $A$ Contractually Reconstructed Research Commons for Scientific Data in a Highly Protectionist Intellectual Property Environment, 66 LAW \& ConTEMP. STUd. 315 (2003); see also Michael J. Madison, Brett M. Frischmann and Katherine J. Strandburg, Constructing Commons in the Cultural Environment, 95 CoRNELL L. Rev. 657 (2010).

28 Reichman, Collapse of the Patent-Copyright Dichotomy, supra note 1; Reichman, Legal Hybrids, supra note 1.

29 Reichman, Saving the Patent System, supra note 22, at 294. 
that they invest time, money and effort to reverse engineer the first comer's know-how from publicly available embodiments by honest means, or that they negotiate upfront licensing agreements and pay directly to acquire such unpublished, up-to-date know-how. In this respect, the technical knowledge generated by routine engineers under trade secrecy laws also differs from that generated by patent laws, which enters the public domain by virtue of disclosure and publication rules. Because the up-to-date, unpublished knowledge generated by routine engineers is only available to those willing to defray either the costs of recreating it from scratch, or the costs of reverse engineering it by honest means, or the costs of licensing it, we are constrained to depict the vast space emerging from their collective efforts as a 'semi-commons', operating on pay-to-play principles, rather than as a true commons or public domain in which everything is freely available to all comers:

The collective knowledge available from [this semi-commons] . . advances by dint of the small-scale contributions of single innovators. These contributions are statistically predictable in the sense that they [usually] inhere in what was already known about existing technical paradigms ... The progressive development of know-how is thus a community project that benefits from the countless small-scale contributions to the prior art by individuals who draw from [both] the public domain [and the semi-commons] to make improvements, and who thereby enrich the [semi-commons] by generating new information that others in the technical community may exploit to their own advantage. ${ }^{30}$

Historically, the legal protection of trade secrets was accordingly organized around a distinctive class of liability rules that stimulated competition in subpatentable improvements by discouraging marketdestructive conduct harmful to the relevant technical community as a whole. This regime did not endow single innovators with any power to remove their subpatentable or otherwise unpatented contributions from the semicommons, as exclusive rights would otherwise allow. On the contrary, trade secrecy law's traditional role was to avoid market failure by enabling entrepreneurs to recoup their investments in small-scale innovation without creating barriers to entry and without impeding qualified second comers from making follow-on applications of others' routine innovations.

30 Id. Here we must concede the possibility that an innovator whose creation rises to the level of a patentable invention may prefer to remain in trade secrecy law if the risks and costs of reverse engineering appear very high. See Lemley, supra note 2; Samuelson and Scotchmer, supra note 1. 


\section{PROBLEMS OF SELF-REVEALING KNOW-HOW AND SMALL-SCALE INNOVATION GENERALLY}

From Figure 8.1, it becomes evident that the space available for both common use of public scientific and technical information at the top, and the space available for applications of know-how at the bottom, will either shrink or expand according to the amount of room occupied by the exclusive rights regimes on both sides of the circle. Within the circle, in Zone 1, are innovations that qualify for patent protection as non-obvious inventions. The size of this space varies with the judicial rigor of the nonobviousness standard, which, until recently, had become relatively low.

In Zones 2 and 3, one finds all the subpatentable innovations that could not qualify for patent protection under the extant non-obviousness standard but which could conceivably qualify for trade secrecy protection if kept legally secret within the conditions set by the UTSA. ${ }^{31}$ Because, however, lots of valuable know-how is borne on or near the face of products distributed in the open market, investors often obtain little or no lead time because second comers can rapidly duplicate the visible know-how without spending time or money to reverse engineer it from scratch. Legislators increasingly respond to this risk of market failure by enacting sui generis exclusive property rights in small-scale innovations, such as industrial designs, utility models, plant breeders' varieties, compilations of data, and the like. As these 'legal hybrid' regimes proliferate in Zone 3, the natural semicommons available to all competitors below the circle correspondingly contracts.

No one familiar with my previous work will be surprised to learn that, owing to a proliferation of hybrid intellectual property regimes, coupled with an expansion of both the domestic and international patent and copyright laws, ${ }^{32}$ both the science commons and the routine engineers' technology pool have lately shrunk in a striking and, many would say, a most alarming fashion. ${ }^{33}$ Professor James Boyle has felicitously called this and related phenomena 'The Second Enclosure, Movement'. ${ }^{34}$

31 See, e.g., Robert Denicola, Chapter 2. Robert G. Bone, Chapter 3.

32 See, e.g., Keith E. Maskus and Jerome H. Reichman, The Globalization of Private Knowledge Goods and the Privatization of Global Public Goods, in International Public GoOds AND Transfer of TeChNology, supra note 15, ch. 1.

33 Reichman, Collapse of the Patent - Copyright Dichotomy, supra note 1; Reichman, Legal Hybrids, supra note 1; Pamela Samuelson et al., A Manifesto Concerning the Legal Protection of Computer Programs, 94 CoLum. L. REv. 2308 (1994).

34 James Boyle, The Second Enclosure Movement and the Construction of the Public Domain, 66 Law \& Contemp. Probs. 33 (2003); see also David Lange, 


\section{PRESERVING THE COMMONS IN A HYPER- PROTECTIONIST LEGAL ENVIRONMENT}

In his article proclaiming the virtues of trade secrecy law as an intellectual property right, Professor Lemley rightly points out that a positive economic effect of this law is to discourage excessive or wasteful investment in maintaining actual secrecy, which would be necessary in the absence of the protection guaranteed by the tenets of trade secrecy law itself. ${ }^{35}$ At the same time, Professor Lemley dismisses self-revealing innovation that can be copied without reverse engineering as of little or no consequence, for the logical reason that, lacking secrecy, it cannot be covered by a law dedicated to the legal protection of secrets.

In reality, that proposition, despite its apparent logic, remains empirically anachronistic in the sense that worldwide intellectual property law has rejected it by refusing to condemn what I have called 'incremental innovation bearing know-how on its face ${ }^{36}$ to the public domain, where Lemley believes it belongs. Disregarding the United States, the rest of the world tends to protect such small-scale, self-revealing know-how under utility model laws (petty patent law), design protection laws, plant variety protection laws (also available in the United States), database protection laws, codified misappropriation laws, and numerous other hybrid legal regimes. ${ }^{37}$ The common denominator of such regimes is that they protect small-scale innovations that lack sufficient novelty to qualify for patent protection and that cannot realistically trigger the secrecy requirement of trade secrecy law either.

Because such innovation tends to bear its investor's know-how on or near its face, second comers (not otherwise legally impeded) can simply extract that know-how by duplicating the products that embody it, without any corresponding costs or time inherent in the process of reverse engineering. In the raw state of affairs, the innovator thus obtains zero lead time in which to recoup his investment in $R \& D$, and the second comer free rides on the first comer's investment, while avoiding any similar cost

Recognizing the Public Domain, 44 Law \& Contemp. Probs. 147 (1981); Jessica Litman, The Public Domain, 39 Emory L.J. 965 (1996).

35 Lemley, supra note 2.

36 See J.H. Reichman, Computer Programs as Applied Scientific Know-How: Implications of Copyright Protection for Commercialized University Research, 452 VAND. L. REV. 639 (1989).

37 Reichman, Legal Hybrids, supra note 1, at 2453-504; Reichman, Green Tulips, supra note 19, at 1753-6; see also Mark Janis, Second Tier Patent Protection, 40 HARV. INT'L L.J. 151 (1999). 
structure of his own. ${ }^{38}$ The hybrid sui generis regimes seek to rectify these disincentives to invest by substituting copyright-like or patent-like regimes of exclusive property rights for the absence of lead time protection under trade secrecy law. ${ }^{39}$

In the United States, instead, where there is officially no utility model law, the patent authorities periodically lower the non-obviousness standard to the point where the patent law itself absorbs an increasingly larger share of the small-scale innovations elsewhere covered by hybrid legal regimes. Thus U.S. patent law protected the paper clip, ${ }^{40}$ which is the quintessential type of self-revealing functional design that utility model laws protect in other countries. Indeed, the low non-obviousness standard practiced in the United States until recently means that U.S. patent law periodically operates as a de facto utility model law in many industrial sectors.

However, a low non-obviousness standard generates high social costs of its own. It blurs the boundaries between inventions, generating litigation and other high transaction costs. ${ }^{41}$ More important, it shrinks both the domain of upstream basic research results freely available to scientists and the downstream domain of small-scale innovation available to routine engineers. ${ }^{42}$ In response, the U.S. Supreme Court periodically elevates the standard of non-obviousness, as it recently did in the KSR decision of $2008,{ }^{43}$ in an effort to promote the granting of 'quality patents'.

An inevitable consequence of these decisions is that a large swath of small-scale innovations, which can readily be duplicated, will fall out of patent protection, only to receive little or no protection in trade secrecy law because they will tend to bear their know-how on or near the face of the products that embody them. Given the predictable outbreak of free riding likely to ensue, and the corresponding disincentives to invest it fosters, one should expect both state and federal courts to push back by invoking various and often questionable doctrines of unfair competition law, as well as trademark or trade dress laws, which can become even more anticompetitive than the proliferating hybrid intellectual property rights under foreign laws. Whether recent U.S. Supreme Court decisions limiting

38 Raskind, Misappropriation, supra note 21; Samuelson and Scotchmer, supra note 1 .

39 Reichman, Legal Hybrids, supra note 1.

$40 \quad$ See Lemley, supra note 2.

41 See Jerome H. Reichman and Rochelle Cooper Dreyfuss, Harmonization Without Consensus: Critical Reflections on Drafting a Substantive Patent Law Treaty, 57 DukE L.J. 85 (2007) (citing authorities).

42 Cf. Boyle, supra note 34.

43 KSR Int'l Co. v. Teleflex Inc., 550 U.S. 398 (2007). 
the use of such ancillary doctrines to supply artificial lead time where otherwise unavailable would hold up against this tide, ${ }^{44}$ should it emerge, remains to be seen.

In Of Green Tulips and Legal Kudzu, which appeared in $2000,{ }^{45} \mathrm{I}$ argued that, while it was unsustainable to cast the bulk of present-day small-scale innovations, with their high front-end costs and ease of duplication, into a world of zero lead time, it was also wrongheaded to address the chronic failure of secrecy under trade secrecy law by means of an expanding set of exclusive property rights that generate overlapping legal entitlements, high transaction costs, and barriers to entry, all of which seriously diminish both innovation and the pace of competition. Above all, the greatest long-term social costs of this flawed strategy are a reduction of upstream inputs into public science (most dramatically under database protection cum copyright laws) and of downstream inputs into applications of know-how to industry.

The correct solution to this problem, in my view, is to replace the failing liability rule of domestic trade secrecy laws, where secrecy keeps diminishing even as the value of vulnerable technical outputs keeps rising, with a general purpose liability rule that would directly address the market failure to which incremental innovation bearing know-how on its face is otherwise susceptible. It is this premise that underlies the 'compensatory liability regime', first developed in Green Tulips. ${ }^{46}$ Ideally, its adoption would render the hybrid regimes of exclusive rights in Zone 3 of Figure 8.1 superfluous and lead to their repeal over time.

Under a compensatory liability regime, a small-scale innovator who operates in Zone 2 would obtain protection against wholesale duplication for a specified period of time. However, that innovator would also labor under an obligation to allow second comers to use his or her know-how for purposes of making improvements, in exchange for a reasonable royalty to be paid over a specified, but relatively short, period of time. Under this regime, there is an ex ante entitlement, in the form of an automatic license, for compensation from follow-on innovators; but there is no possibility of excluding the second comer from making those improvements. If many improvers emerge, the first comer may experience lottery effects from the

44 Traffix Devices, Inc. v. Marketing Displays, Inc, 532 U.S. 23 (2001); WalMart Stores, Inc. v. Samara Brothers, Inc. 529 U.S. 205 (2000); Bonito Boats, Inc. v. Thunder Craft Boats, Inc., 489 U.S. 141 (1989).

${ }_{45}$ Reichman, Green Tulips, supra note 19; see also Jerome H. Reichman, of Green Tulips and Legal Kudzu: Repackaging Rights in Subpatentable Innovation, in ExPANDING THe Boundaries of INTEllectual Property 23 (Rochelle Dreyfuss $e t$ al. eds., Oxford University Press, 2001).

46 See Reichman, Green Tulips, supra note 19, at 177-97. 
contributions of his de facto partners, and that same first comer may also utilize some of their improvements to advance his or her own competitive position by paying a corresponding reasonable tithe in exchange. ${ }^{47}$

I will not delve more deeply into the intricacies of a 'compensatory liability regime' within the confines of this short chapter on the legal logic of trade secrecy law. Suffice it to say, this proposed regime attempts to address the biggest problem facing trade secrecy law today, which is not its lack of systemic logic, but its growing inability to function in a world without significant secrecy in important sectors of technological innovation. Absent such an alternative regime, we may expect to witness a continuing unraveling of the trade secrecy paradigm, with mounting aberrations, such as the criminalization of trade secrecy law in the United States ${ }^{48}$ and the adoption of an exclusive right to trade secrets in Italy. ${ }^{49}$ To the extent that these and other aberrations cumulatively exert a chilling effect on innovation, we end up more or less where market failures from too much free riding would otherwise have carried us in the raw state of affairs.

In contrast, the compensatory liability model seeks to replace a timetested liability rule rooted in secrecy with a portable liability rüle covering applications of know-how to industry that is detached from the requirement of secrecy (but not that of a modicum of novelty). It can thus co-exist with trade secrecy law and allow small-scale innovators two different, but pro-competitive options. If the innovator chooses the compensatory liability regime, it will provide him or her with more or less the same remedies as trade secrecy law. It would inhibit wholesale duplication as a dishonest form of reverse engineering, ${ }^{50}$ and allow second comers to 'pay' for lessened lead time advantages by investing in improvements of their own and then sharing some of the resulting profits with the first comer.

\section{CONCLUSION}

I will end by noting four additional benefits likely to flow from adoption of a compensatory liability regime for small-scale innovation. First, such a second-tier regime would actually reinforce the courts' willingness to

47 Fór details, see generally Reichman, Green Tulips, supra note 19, at 177-90.

48 Rochelle Cooper Dreyfuss, Trade Secrets: How Well Should We be Allowed to Hide Them? The Economic Espionage Act of 1996, 9 Fordham Intell. Prop. Media \& EnT. L.J. 1 (1998).

49 See Ghidini \& Falce, Chapter 6.

so See Samuelson and Scotchmer, supra note 1 (analysis of plug mold statutes in this regard). 
maintain a stiff non-obviousness standard, and thus remove the clutter that accumulates both upstream and downstream when weak patents are issued. The existence of a second-tier liability rule would reinforce the judges' scrutiny of obviousness, by assuring them that those innovations that fail the test will nonetheless be rescued from wholesale duplication and free riding forms of market failure (without fostering corresponding barriers to entry). This could prove to be of particular benefit to the information technology sector, which has been suffocating under the weight of too many patents, but which seems ever more comfortable with existing uses of liability rules.

Second, resort to a compensatory liability rule for small-scale innovation should obviate the need for adding more hybrid regimes of exclusive property rights to Zone 3 , where the cumulative social costs are becoming unsustainable. Third, once set in place, a compensatory liability model can be adapted to the needs of different industries without damage to its basic mechanisms Just as the semiconductor chip industry had some particular understanding about the boundaries of reverse engineering in the Semiconductor Chip Protection Act of $1984,{ }^{51}$ so different sectors can contractually adjust the liability model to their own needs, within outer limits set by legislators, relevant regulators or industry governance boards (when an industry voluntarily adopts a liability rule for itself).

Finally, once a compensatory liability regime becomes a more familiar alternative intellectual property model, it can be adapted to address numerous problems at the margins that may otherwise seem intractable. For example, in previous articles, I have tried to show how such a liability rule could resolve hard problems encountered with respect to traditional knowledge, ${ }^{52}$ clinical trial data, ${ }^{53}$ and the quest for an acceptable form of database protection..$^{54}$ This regime also has a promising future in supporting the formation of pooled inputs for scientific research where the possibility of downstream applications might otherwise undermine the sharing norms of science..$^{55}$

51 Semiconductor Chip Protection Act of 1984 (SCPA), title III of Pub. L. No. 98-620, 98 Stat. 3335, 3347 (November 8, 1984) codified at 17 U.S.C. $\$ \S 901-14$ ( $\$ 06$ expressly permits reverse engineering); see also Raskind, Semiconductor Chip Act, supra note 21.

52 Reichman and Lewis, supra note 15.

53 Reichman, Role of Clinical Trial Data, supra note 5.

54 Jerome H. Reichman and Pamela Samuelson, Intellectual Property Rights in Data?, 50 VAND. L. REV. 51, 145-51 (1997); Reichman and Uhlir, supra note 27.

55 Arti K. Rai et al., Pathways Across the Valley of Death: Novel Intellectual Property Strategies for Accelerated Drug Discovery, 8 Yale J. Health Pol'y L. \& Eтнісs 1, 25-8 (2008); see also Jerome H. Reichman, Tom Dedeurwaerdere and 
In this regard, at least one important international treaty concerning plant genetic resources for food and agriculture has actually embodied a rudimentary model of such a compensatory liability regime. ${ }^{56}$ Efforts are underway to develop a more refined application of such a regime to microbial science in order to mediate between the demands of developing countries for control of their local genetic resources and the needs of the worldwide scientific community. ${ }^{57}$ It also seems likely that liability rules could play an important role in enabling developing countries to accommodate patented climate-change technologies to their own needs over time. ${ }^{58}$

Paul F. Uhlir, Designing the Microbial Research Commons: Global Intellectual Property Strategies for Accessing, and Using Essential Public Knowledge Assets, ch. 2 (Draft version, February 2, 2011) (unpublished manuscript, on file with authors).

56 International Treaty on Plant Genetic Resources for Food and Agriculture, November 3, 2001, available at www.fao.org/legal/treaties/033f-e.htm; Laurence R. Helfer, Using Intellectual Property Rights to Preserve the Global Genetic Commons: The International Treaty on Plant Genetic Resources for Food and Agriculture, in International Public Goods and Transfer of Technology, supra note 15 , at $217-24$.

57 Reichman, Dedeurwaerdere and Uhlir, supra note 55, chs. 2 and 6.

58 See, e.g., Jerome Reichman, Arti K. Rai, Richard G. Newell and Jonathan B. Wiener, Intellectual Property and Alternatives: Strategies for Green Innovation, Chatham House Energy, Environment and Development Programme, Paper No. 08/03 (2008), available at www.chathamhouse.org.uk/files/13097_1208eedp_duke. pdf. 